\title{
AN ASSESSMENT OF KNOWLEDGE, ATTITUDE AND PRACTICE (KAP) TOWARDS RECYCLING ACTIVITY IN KUANTAN PAHANG, MALAYSIA
}

\section{MOHDARMI ABU SAMAH ${ }^{1}$, NABILA MAT YUSOFF ${ }^{2}$, ROSLIZAMOHD SALIM ${ }^{3} \&$ MOHDKHAIRULAMRI KAMARUDIN ${ }^{4}$}

${ }^{1,2,3}$ Kulliyyah of Science, International Islamic University Malaysia, Jalan Sultan Ahmad Shah, Bandar InderaMahkota, 25200 Kuantan, Pahang DarulMakmur

${ }^{4}$ Faculty of Applied and Social Sciences (FSSG), Universiti Sultan Zainal Abidin, Gong Badak Campus, 21300 Kuala Nerus, Malaysia Selangor, Malaysia

This study was conducted among the householders at residential area in kuantan at 6 places in Kuantan. It was involving 308 of respondents from all 6 places in Kuantan (Bukit Rangin, Bukit Istana, Astana View, Jaya Gading, Taman RasauPerdana and Seri DamaiPerdana). The main purpose of this study was to investigate the level of knowledge, attitude and practice (KAP) of household recycling towards solid waste management. Besides that, the study also was conducted to identify which factors among the demographic profiles of gender, ages, household incomes and level of education could give the significantly different to KAP. Then, this study investigated the significant relationship among of each KAP variables. Data for this study was obtained in quantitative studies through questionnaires and analysing them using the SPSS software. This study was using the statistically testing of t-test, One-Way ANOVA and Pearson correlation. For genders the statistical testing's using was the independent t-test, and it was found that that males and females did not significantly different $(p>0.05)$ towards the KAP of household recycling.
\end{abstract}

KEYWORDS: Knowledge, Attitude, Practice and Recycling

Received: May 21, 2020; Accepted: Jun 11, 2020; Published: Jul 21, 2020; Paper Id.: IJMPERDJUN2020400

\section{INTRODUCTION}

Malaysia has been throughout the years encountering rapid growth population, urbanization and industrialization. Now, the population is around 28.5 million and over $70 \%$ of this was reported to be living in the urban zones. Thus, these cause the greater the generation of municipal solid waste (Badgie et al., 2012; Fauziah and Agamuthu, 2012). The Government of Malaysia through the Ministry of Housing and Local Government (KPKT) launched a recycling campaign in 1993 but the effort failed to achieve its objective. This is due to the increase in waste generation to 0.7 kilograms per capita per day in 1993 and continues to rise to 0.8 kilograms per capita per day in 1994 (Seow and Ismail, 2003; Seow and Jamaludin, 2004).

The Government decided to re-launch the recycling campaign in 2001 with more money allocated for publicity and educating the public (UPE, 2006). At the end of 2001, solid waste generation increased by 16,200 tonnes a day and increased by 19,100 tonnes per day in 2005 (UPE, 2006). In 2012 the solid waste generation increased by 28,565.32 tonnes a day. The waste management method in Malaysia is 95 percent through the landfill. Dependence on landfills will increase greenhouse gas emissions by $50 \%$ by 2020 (KPKT, 2012). The increase in population has also resulted in increasing of waste generation, especially of domestic waste. This factor has 
contributed to the opening of a new solid waste site to accommodate the increased amount of solid waste (Anuar, 2016). Therefore, without proper management on the solid waste management this condition may be worse. It also may cause the environmental pollution.

An efficient of solid waste management in sustainability of urban development is important. The rate of waste generator is more increasing especially in a town. It becomes main challenges towards local authorities. This issue becomes a big challenging to local authority. One of initiative that has been practiced in our country for reducing waste generation is recycling. However, recycling rates in Malaysia are still low compared to neighbouring countries (Abas, 2013). Hence, the number of waste disposal sites in Malaysia is increasing from year to year to accommodate the quantity of solid waste generated from households, industries, construction sites and educational institutions (schools, colleges, universities). The increase in the number of waste disposal sites will negatively affect the well-being of the environment, social and economic development. Easy and efficient recycling systems and technologies need to be introduced to the community to improve recycling practices (Abas, 2013).

This study is related with the Knowledge, Attitude and Practice (KAP) on Kuantan's residents about the household recycling waste. A KAP survey is a representative of investigation on a particular population to collect information on what is known, believed, and done in relation to a specific topic-in this case, solid waste management on household recycling. KAP survey data are important to help plan, implement and evaluate advocacy, communication and social mobilization work. It's gather information about what respondents know about recycling and solid waste management (SWM), what they think about people practicing recycling, and what they actually do with solid waste management.

\section{METHODOLOGY}

This study is using a cross-sectional study by conducting the KAP survey among Kuantan's residents who are living in the area having of municipal of household waste services. This study also involved both quantitative and qualitative approach. A random sample of 319 respondents constituted the study population. Data were gathered using a structured questionnaire. T-test, ANOVA and Pearson Correlation were applied to identify the association among variables.

\section{Location Selection}

This study was conducted at residential area in Kuantan, Pahang. Kuantan is the state capital of Pahang, Malaysia. Pahang is on a peninsula with divided into eleven districts of Kuantan, Pekan, Rompin, Maran, Temerloh, Jerantut, Bentong, Raub, Lipis, Cameron Highlands and Bera. Kuantan has devided to 6 Mukim, 2 cities and 1 town. For mukim, it is consisting of;

- MukimBeserah

- Mukim Hulu Kuantan

- Mukim Hulu Lepar

- Mukim Kuala Kuantan

- MukimPenor

- Mukim Sungai Karang.

For city, it is Bandar Gambang and Bandar Kuantan. Lastly for town, it is PekanTanjung Lumpur (MNRE, 2018). 
The size of total area of Kuantan area is $2,960 \mathrm{~km}$ persquare $(296,042.09$ hectares), or about $8.2 \%$ of the total area of the Pahang state (NADM, 2007).

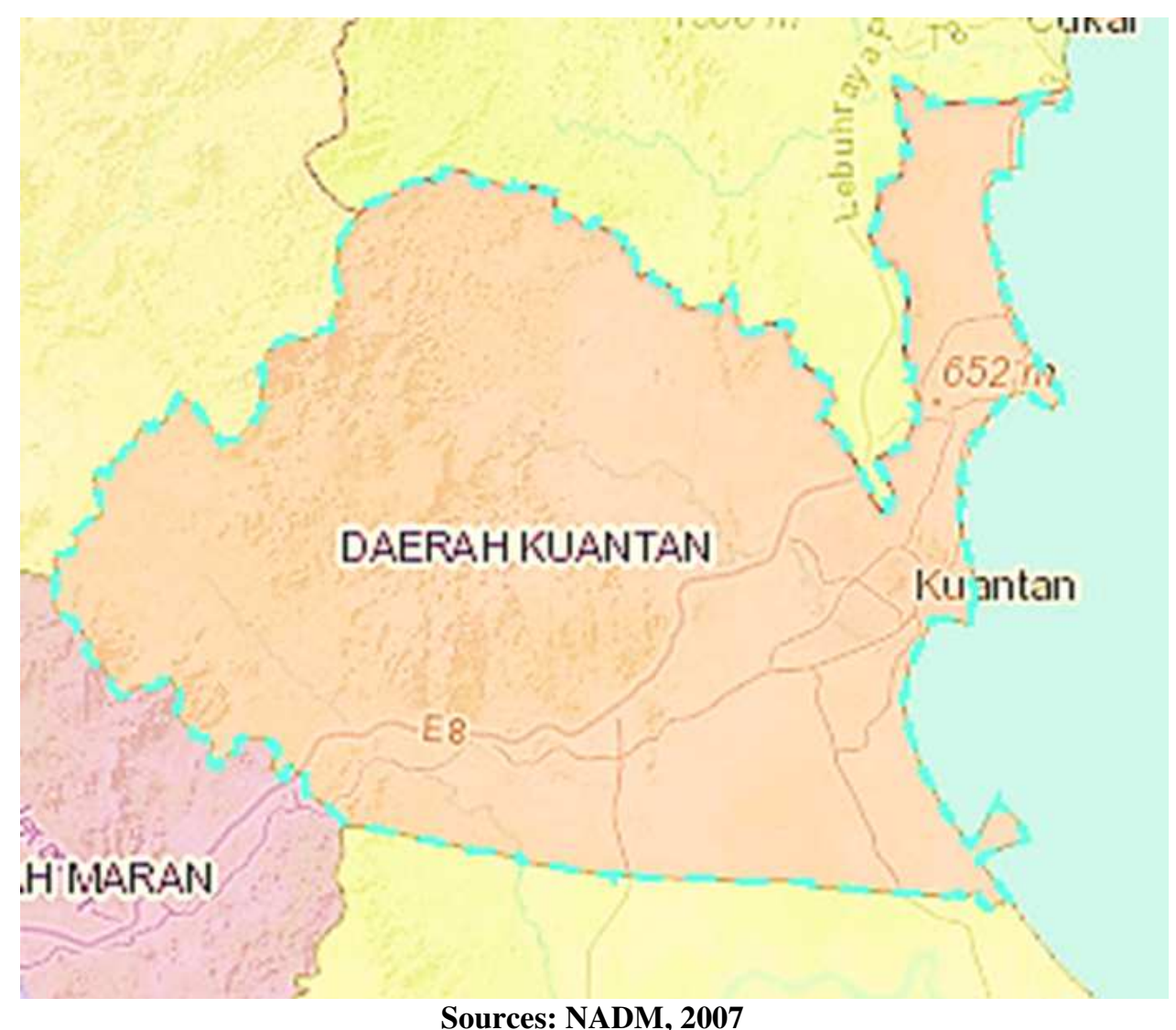

Sources: NADM, 2007

Figure 3.1: Maps of Kuantan

The municipal solid waste service in Pahang is under the Alam Flora Sdn. Bhd. Alam Flora Sdn. Bhd. (2018) stated that Pahang is one of the regions that done the collection service by them. Furthermore, Kuantan is one of ten states in Pahang service area that had been operated by Alam Flora Sdn. Bhd. for MSW services. This research is needed to conduct the survey about the household waste, thus the place chosen must be from the respondent that living in the household area and the place are having the SWM. The selected areas in Kuantan that needed to conduct the survey from the respondents are Bukit Rangin, Bukit Istana, Taman RasauPerdana, Astana View, Jaya Gading and Seri DamaiPerdana. All the places are chosen because they are stated in the Mukim Kuala Kuantan and also near to the IIUM Kuantan.

\section{Sampling Method}

Sampling is a research strategy to use by researchers to get the information about a population from an individual's population. For this study the respondents are selected randomly. Random sampling means each subject is chosen randomly and by chance, with a known probability of being selected from a larger population. The sample is an unbiased representation of the total population. If for some reasons, the sample does not represent the population, the variation is called a sampling error (The Economic Times, 2018). 


\section{Sample Size}

According to World Population Review (2017), Kuantan has a population of 366 299. The population of Pahang is made up of different races and nations like Malay, Chinese and Indian. Suitable sample size is needed to get the right estimation of population. The large sample size is highly cost due to data collection, coding and analysis of data. Meanwhile, for small sample size will give lack of information to make a conclusion. Thus, sample size determination is an important process in statistically aspect and also to the budget of research and analysis. The sample size of this is calculated by using Taro Yamane formula with $94 \%$ of confident level (Haider et al., 2015). The calculation formula of Taro Yamane is presented as follows;

$\mathrm{n}=\mathrm{N} /\left(1+\mathrm{N}\left(\mathrm{e}^{\wedge} 2\right)\right)(1)$

Where:

$\mathrm{n}=$ size of the sample

$\mathrm{N}=$ total population of selected areas

$\mathrm{e}=$ accepted margin of error in estimates.

Substitute numbers in formula:

$\mathrm{n}=(366299) /(1+366299(\llbracket 0.06 \rrbracket \wedge 2))(2)$

$\mathrm{n}=278$ (Rounded)

After calculated the sample size by substituting the numbers into the Yamane formula, the numbers of sample is 277.5672 persons. In order to obtain reliable of data, sample size has increased from 278 to 300 persons.

\section{Pilot Study}

A pilot study was conducted before the real data collection. It is for ensure that the questionnaires are easy to understand and the questions are pass the reliability test in SPSS software using Cronbach Alpha. The survey had been edited almost twice time. The first trial is distributed among ten IIUM's students and it is to know that the sentences and questions are easy to understand. However, there are a lot of scientific terms and the questions are hard to understand. The respondents need to fill in the answers and there are a lot of repetitive questions. Then, for second trial, the questionnaire is changed to Likert scale and devided into 5 parts (demographic, knowledge, attitude, practice and suggestion). The second trial is conducted among 30 respondents from International Islamic College University Selangor (KUIS) but out of 6 is not filling the questionnaire correctly. Then, the 24 data collected from the respondents are inputted in SPSS. As stated by Priya and Shruti (2015), Cronbach Alpha is a reliability test conducted within SPSS in order to measure the internal consistency for example reliability of the measuring instrument, for this study the instrument use is questionnaire. It is most commonly used when the questionnaire is developed using multiple Likert scale statements and therefore to determine if the scale is reliable or not.

\section{Respondent}

There are 24 out of 30 respondents of the pilot study and most of they are from KUIS. Table of the analytical descriptive of demographic profile from the pilot study is shown below. 
Table 3.1: The Demographic Profile of the Pilot Study

\begin{tabular}{|c|c|c|}
\hline Demographic Profile & Frequency & Percent (\%) \\
\hline $\begin{array}{l}\text { Age } \\
21-30 \\
31-40 \\
41-50 \\
51-60 \\
61-70\end{array}$ & $\begin{array}{l}8 \\
8 \\
7 \\
0 \\
1\end{array}$ & $\begin{array}{c}33.3 \\
33.3 \\
29.2 \\
0.0 \\
4.2\end{array}$ \\
\hline $\begin{array}{l}\text { Gender } \\
\text { Male } \\
\text { Female }\end{array}$ & $\begin{array}{l}11 \\
13\end{array}$ & $\begin{array}{l}45.8 \\
54.2\end{array}$ \\
\hline $\begin{array}{l}\text { Status } \\
\text { Single } \\
\text { Married } \\
\text { Divorced / Separated }\end{array}$ & $\begin{array}{c}10 \\
13 \\
1\end{array}$ & $\begin{array}{c}41.7 \\
54.2 \\
4.2\end{array}$ \\
\hline $\begin{array}{l}\text { Education } \\
\text { Certificate } \\
\text { Bachelor } \\
\text { Master } \\
\text { PhD }\end{array}$ & $\begin{array}{c}3 \\
14 \\
1 \\
6\end{array}$ & $\begin{array}{c}12.5 \\
58.3 \\
4.2 \\
25.0\end{array}$ \\
\hline $\begin{array}{l}\text { Races } \\
\text { Malay } \\
\text { Chinese }\end{array}$ & $\begin{array}{c}23 \\
1\end{array}$ & $\begin{array}{c}95.8 \\
4.2\end{array}$ \\
\hline $\begin{array}{l}\text { Type of work } \\
\text { Private } \\
\text { Government } \\
\text { Self-employed } \\
\text { Unemployed }\end{array}$ & $\begin{array}{c}18 \\
1 \\
2 \\
3\end{array}$ & $\begin{array}{c}75.0 \\
4.2 \\
8.3 \\
12.5\end{array}$ \\
\hline $\begin{array}{l}\text { Household income } \\
\text { < RM1000 } \\
\text { RM1001-RM3000 } \\
\text { RM3001-RM5000 } \\
\text { > RM5001 }\end{array}$ & $\begin{array}{l}4 \\
6 \\
7 \\
7\end{array}$ & $\begin{array}{l}16.7 \\
25.0 \\
29.2 \\
29.2\end{array}$ \\
\hline $\begin{array}{l}\text { Number of household } \\
1-6 \\
7-12\end{array}$ & $\begin{array}{c}20 \\
4\end{array}$ & $\begin{array}{l}83.3 \\
16.7\end{array}$ \\
\hline $\begin{array}{l}\text { Period of staying (years) } \\
1-5 \\
6-10 \\
11-15 \\
16-20 \\
21-25 \\
26-30 \\
31-35 \\
>36\end{array}$ & $\begin{array}{l}5 \\
6 \\
5 \\
3 \\
1 \\
1 \\
1 \\
3\end{array}$ & $\begin{array}{c}20.8 \\
25.0 \\
20.8 \\
12.5 \\
4.2 \\
4.2 \\
4.2 \\
12.5\end{array}$ \\
\hline
\end{tabular}




\begin{tabular}{|l|c|c|}
\hline Period of staying (years) & 5 & 20.8 \\
$1-5$ & 6 & 25.0 \\
$6-10$ & 5 & 20.8 \\
$11-15$ & 3 & 12.5 \\
$16-20$ & 1 & 4.2 \\
$21-25$ & 1 & 4.2 \\
$26-30$ & 1 & 4.2 \\
$31-35$ & 3 & 12.5 \\
$>36$ & & \\
& & \\
\hline
\end{tabular}

\section{Reliability Test}

In order to determine the reliably of the questionnaire, according to Stephanie (2017), the Cronbach's alpha test was conducted. In 1951, Lee Cronbach was developed the Cronbach's alpha. It measures reliability, or internal consistency. "Reliability" is how well a test measures what it should. It is tested to see if multiple-question Likert scale surveys are reliable. These questions measure latent variables (hidden or unobservable variables).

Table 3.2: A Rule of Thumb for Interpreting Alpha The Likert Scale Questions

\begin{tabular}{|c|l|}
\hline Cronbach's alpha, $\boldsymbol{\alpha}$ & \multicolumn{1}{|c|}{ Internal consistency } \\
\hline$\alpha \geq 0.9$ & Excellent \\
\hline $0.9>\alpha \geq 0.8$ & Good \\
\hline $0.8>\alpha \geq 0.7$ & Acceptable \\
\hline $0.7>\alpha \geq 0.6$ & Questionable \\
\hline $0.6>\alpha \geq 0.5$ & Poor \\
\hline $0.5>\alpha$ & Unacceptable \\
\hline
\end{tabular}

The acceptable reliability value is within 0.7 to 0.8 . Therefore if the questionnaire's reliability result is more than 0.6 then the questionnaire is considered "questionable" for the internal consistency. For this pilot study, the value for reliability coefficient is more than 0.859 which is good reliability coefficient. Appendix A shows the reliability result using the SPSS.

\section{RESULTS AND DISCUSSIONS}

This variable is using the independent sample t-test. The independent sample t-test is using when investigating the difference between independent groups (males and females) on an approximately normal dependent variable and the following assumptions are not markedly violated. Assumption 1 (observations are independent) probably is met because the genders are not related pairs. SPSS will automatically test the Assumption 2 (the variances of the dependent variable in the two populations are equal) with the Levene's test for equal variances. Then, for Assumption 3 (normally distributed) already tested and the data is normally distributed. The t-test output of SPSS is on the Appendix G.

The left two columns of numbers are the Levene's test for the assumption that the variances of the two groups are equal. This is not the $\mathrm{t}$ test; it only assesses an assumption. If this $\mathrm{F}$ test is not significant (as in the case of knowledge and practice), the assumption is not violated, and one uses the Equal variances assumed line for the $t$ test and related statistics. However, if Levene's $\mathrm{F}$ is statistically significant (Sig. $<0.05$ ), as is true for attitude, then variances are significantly different and the assumption of equal variances is violated. In that case, the Equal variances not assumed line is used, and the $t, d f$, and Sig. are adjusted by the program. The hypotheses testing of this part are: 
- Ho1 Male and female respondents are no significantly different in regard to their mean score of KAP

- HA1 Male and female respondents are significantly different in regard to their mean score of KAP

Table 4.5: Comparison of Male and Female of Selected Area in Kuantan on KAP Means Score of Household Recycling ( $\mathrm{n}=149$ and 159 males)

\begin{tabular}{|c|c|c|c|c|c|}
\hline Variable & M & SD & t value & df & p value \\
\hline Knowledge & & 0.351 & 0.701 & 306 & 0.484 \\
\hline Male & 4.376 & 0.404 & & & \\
\hline Female & 4.407 & 0.449 & & & \\
\hline Attitude & & 0.387 & & & \\
\hline Male & 4.480 & & & $305.91^{*}$ & \\
\hline Female & 4.400 & & & & \\
\hline Practice & & & & & \\
\hline Male & 4.005 & 0.445 & 1.003 & & 0.077 \\
\hline Females & 3.953 & 0.467 & & & \\
\hline
\end{tabular}

*The $t$ and df were adjusted because variances were not equal.

Table 4.5 shows that males were not significantly different from females on attitude $(p=0.077)$. Inspection of the two group means that the mean the average attitude score for female $(M=4.400)$ is lower than the mean score of males $(M$ $=4.480)$. Meanwhile, males also did not differ significantly from females on knowledge $(\mathrm{p}=0.484)$ and practice $(\mathrm{p}=$ $0.317)$.

Males from the selected area in Kuantan have same attitude towards the recycling with female's attitudes. For knowledge and practice of recycling, males and females are same. It is supported by a research done by Jibril et al. (2014) that they also found males and females have no significant different on practicing of the recycling. It is not only in the attitude towards recycling males and females were significantly different but they also differ in the aspect of environment

\section{CONCLUSIONS}

In conclusion, this study was successfully carried out to evaluate the level of KAP among the household in the selected area Kuantan, to study which factors in the demographic profile show significant different towards the KAP of household recycling. Then, to identify the relationship among of all the KAP variables are strong. Primary data were collected by convenient sampling to 308 respondents. This study has shown that there is no significance difference in KAP among based on genders $(\mathrm{p}>0.05)$ towards the KAP of household recycling.

\section{REFERENCES}

1. Abas, M. A. (2013).PelupusanSisaPepejal: KajianKitarSemulaSatuAliran di PusatPengajianSainsMatematikdanSains Komputer. Retrieved October 6, 2017 from https://www.researchgate.net/publication/271102751.

2. Alam Flora Sdn. Bhd. (2018).Collection Services. Retrieved March 15, 2018 from http://www.alamflora.com.my/collectionservices.html

3. Anuar, I. (2016). BahayaTapakPelupusanSisaPepejal. Kuala Lumpur: Dewan Bahasa danPustaka.

4. Badgie, D., Samah, M. A., Manaf, L. A., \& Muda, A. B. (2012). Assessment of Municipal Solid Waste Composition in Malaysia: Management, Practice and Challenges. Polish Journal of Environmental Studies, 21(3), 539-547.

5. Adeyemo, FLORENCE O., and G. O. Gboyesola. "Knowledge, Attitude and Practices on Waste Management of People Living in the University Area of Ogbomso, Nigerian." International Journal of Environment Ecology, Family and Urban Studies 3 
(2013): 51-56.

6. Haider, A., Amber, A., Ammara, S., Mahrukh, K.S., \& Aisha, B. (2015)..Knowledge,Perception and Attitude of common People towards Solid Waste Management A case study of Lahore, Pakistan. International Research Journal of Environmental Sciences, 4(3), 100-107.

7. Jibril, D. J., Sipan, I. B., Sapri, M., Shika, S. A. \& Abdullah, S. (2014) Reduce Reuse Recycle practice in solid waste management for academic environment.

8. Meenakshi, V., and J. VenkataPirabu. "A scale to measure the attitude of rice farmers towards indigenous traditional knowledge practices." International Journal of Agricultural Science and Research (IJASR) 5.4 (2015): 167-172.

9. Kementerian Perumahandan Kerajaan Tempatan (2012).PerangkaanTerpilih KPKT 2012: Program Pengurusan Sisa $\begin{array}{llll}\text { Pepejal. } \quad \text { May, } & \text { 2018, } & \text { from }\end{array}$ http://www.kpkt.gov.my/kpkt/fileupload/perangkaanterpilih/Pt2012/jun/PROGRAM_PENGURUSA_SISA_PEPEJAL.pdf

10. Ministry of Natural Resources and Environment.(2018). Aplikasi Carian Koddan Nama Sempadan Pentadbiran Tanah (UPI). Retrieved March 20, 2018, from ～https://mygos.mygeoportal.gov.my/upi/

11. Naikwade, Shital, R. Gopal, And Nitin Sippy. "A Study On Working Women's Attitude Towards Allopathy Or Ayurveda \& Yoga System Of Medicine For Managing The Lifestyle Diseases With Special Reference To Western Suburbs Of Mumbai."International Journal Of Business Management \& Research (IJBMR) 6. 1, Feb 2016, 57-64

12. National Audit Department Malaysia. (2007). AktivitidanKajianKhas Jabatan/AgensiKerajaanNegeri March

Pahang.Retrieved https://www audit.gov.my/docs/BM/4Laporan\%20Ketua\%20Audit\%20Negara/2Negeri/Pahang/5.aktiviti_kajian_2007.PDF.

13. Priya, C. and Shruti, D. (2015). Reliability Test in SPSS using Cronbach Alpha.Retrieved $\quad$ April $\quad 3, \quad 2018 \quad$ from https://www.projectguru.in/publications/reliability-test-cronbach-alpha/.

14. Moses, Chinonye. "Entrepreneurship Education And Student's Life Challenging Situations: An Empirical Study Of Covenant University, Ota, Ogun State, Nigeria." International Journal of Business and General Management (IJBGM) 3.4 (2014): 1-10.

15. Seow, T. W. and M. Ismail (2003). Solid Waste Management in Malaysia: Its Problems and Solution. Proceedings SARDINIA 2003: Ninth International waste Management and Landfill Symposium. Italy: GraficheGhiani.

16. Seow, T. W. and Jamaluddin, M. J. (2004).PengurusanSampahSarapPepejal di Malaysia:MasalahdanPenyelesaian. Seminar KebangsaanGeografidanAlamSekitardalamPendidikandan Pembangunan Negara. Perak: UniversitiPendidikan Sultan Idris.

17. Stephanie. (2014). Cronbach's Alpha: Simple Definition, Use and Interpretation. Retrieved April 3, 2018 from http://www.statisticshowto.com/cronbachs-alpha-spss/

18. The Economic Times.(2018). Definition of 'Random Sampling'.Retrieved April 2, 2018 from https://economictimes.indiatimes.com/definition/random-sampling.

19. Unit PerancangEkonomi (2006). Rancangan Malaysia Kesembilan 2006-2010. Putrajaya: JabatanPerdanaMenteri,

20. World Population Review. (2017). Retrieved October 26, 2017, from http://worldpopulationreview.com/countries/malaysiapopulation/cities/ 